University of Rhode Island

DigitalCommons@URI

3-24-2014

\title{
The Adaptive Venue Shopping Framework: How Emergent Groups Choose Environmental Policymaking Venues
}

Aaron J. Ley

University of Rhode Island, ajley@uri.edu

Edward P. Weber

Follow this and additional works at: https://digitalcommons.uri.edu/psc_facpubs

The University of Rhode Island Faculty have made this article openly available.

Please let us know how Open Access to this research benefits you.

This is a pre-publication author manuscript of the final, published article.

Terms of Use

This article is made available under the terms and conditions applicable towards Open Access

Policy Articles, as set forth in our Terms of Use.

\section{Citation/Publisher Attribution}

Aaron J. Ley \& Edward P. Weber (2015) The adaptive venue shopping framework: how emergent groups choose environmental policymaking venues, Environmental Politics, 24:5, 703-722, DOI: 10.1080/ 09644016.2015 .1014656

Available at: https://doi.org/10.1080/09644016.2015.1014656

This Article is brought to you for free and open access by the Political Science at DigitalCommons@URI. It has been accepted for inclusion in Political Science Faculty Publications by an authorized administrator of DigitalCommons@URI. For more information, please contact digitalcommons-group@uri.edu. 
The Adaptive Venue Shopping Framework: How Emergent Groups Choose Environmental Policymaking Venues

Aaron J. Ley, Ph.D. Department of Political Science

University of Rhode Island

ajley@uri.edu

Edward P. Weber

Ulysses G. Dubach Professor

School of Public Policy

Oregon State University

edward.weber@oregonstate.edu 


\begin{abstract}
Scholars have succeeded in producing several explanations for why groups choose to pursue their policymaking goals in different venues. A synthetic framework that explains the choices these groups make is developed through two case studies describing a conflict over the environmental problem of agricultural field burning. Emergent, boundedly rational, groups with a mission to clear the air of the pollutants associated with field burning, are found to be choosing venues by strategically assessing the institutional context. The particular institutional context that matters involves three primary elements: the group's mix of resources, opponents' resource strengths, and the degree of venue accessibility. These initial choices allow groups to generate new resources, to learn about which strategies do and do not work, and to change venues on the basis of their new resources and what they have learned.

Keywords: Venue Choice, Field Burning, Policy Change, Adaptive Venue Shopping, adaptive learning, collaboration
\end{abstract}




\section{Introduction}

The world of environmental politics and policy is no stranger to policy conflict driven by political interests representing changing societal values and practices at odds with the legal status quo (Brick and Cawley 2008). Many of these policy battles are resolved locally, but the high stakes environmental problems that groups and policymakers are struggling over are increasingly taking on global dimensions (Rootes 2013). It has become common for environmental advocacy groups seeking change, especially newly formed groups, to encounter major resistance from entrenched interests benefiting from, and using their resources to, prevent change. This means that nascent groups, often lacking large and politically mobilized constituencies, are outgunned both financially and in their application of legal and/or scientific expertise in policymaking venues, 'the institutional locations where authoritative decisions are made concerning a given issue' (Baumgartner and Jones 1993, p. 32). One consequence is that the policymaking venues available to them, such as legislatures, courts, administrative agencies and, increasingly, collaborative institutions (see Lubell, Henry and McCoy 2010), remain dominated by established interests who successfully resist change. How do groups navigate this difficult policy terrain when their adversaries have come to dominate the policymaking venues that make policy change possible?

Scholars have not overcome the challenge of providing a sufficient answer to this question despite its practical and theoretical importance to all groups that are seeking policy change. In order to bring greater clarity to this question, we explore how newly formed groups place demands on various institutional venues during a major, ongoing controversy over the 
practice of agricultural field burning in the U.S. states of Washington and Idaho. Employing a multiple case study approach, we ask, 'how might a nascent environmental group, or any group for that matter, navigate a political system marked by multiple policy venues in their quest for change?' Interestingly, we find that the newly formed environmental and public health interest groups in each case chose to pursue the very same policy goals - clean air - in different policy venues. Why?

Through personal interviews with key participants and archival research, we identify three factors that prove critical for improving our understanding of the complex process of venue choice: the behavior of newly emerged groups; the institutional context in which they make decisions about choosing venues; and the role that learning plays in choosing strategies for pursuing their primary policy goals. Our framework builds on the insights of the Ecology of Games Framework developed by Lubell (2013); it assumes the existence of multiple venues at various levels of the American system. Our core theoretical argument, and synthetic framework, the Adaptive Venue Shopping (AVS) Framework, is grounded in the idea that newly emerged groups base their strategic choices about where to pursue their policy goals by assessing the institutional context in which they are embedded. This process, driven by the trial-and-error decision-making typical of boundedly rational groups, entails an important degree of adaptive learning about which strategies do and do not work. The products of this adaptive learning process are deliberate changes in strategy that lead to venue change (see Heikkila and Gerlak 2013). Further, as adaptive learning occurs, groups begin generating and assembling resources that can be transferred from one institutional venue to another, thus improving their prospects for successfully altering the policy status quo. 
Before exploring and developing the empirical evidence in the two cases of field burning, we provide a full discussion of the AVS Framework, along with the research methods employed for this study. After laying out our theoretical argument in more detail, we describe the institutional context that shapes the decisions that are made by emergent environmental groups, the methodology for our multiple case study design, and our findings.

\section{Emergent groups, institutional context, and adaptive venue shopping}

A number of theories have traditionally been used to better understand the process of venue shopping in the American political system. First, instrumental rational choice theories grounded in bounded rationality (e.g., cognitive limitations, imperfect information) argue that 'coalitions will seek to utilize their resources efficiently [and strategically]...to produce the most policy benefits for the cost incurred' when pursuing policy change in the context of multiple intergovernmental venues (Sabatier and Jenkins-Smith 1999, p. 142, Weible 2007, Weible and Sabatier 2007). Second, Lubell et al. (2010) accept these same behavioral assumptions and develop the ecology of (policy) games involving multiple policy venues. In the ecology of games, actors prefer particular venues and thus 'spend energy developing [their skills and resources] in the new venue and move away from other [possible] games [or venues]' (Lubell et al. 2010, p. 290). This approach challenges the analytical tradition of focusing on one policy venue at a time, and emphasizes how adaptive policy systems furnish policies that are the product of multiple decisions being made in multiple venues over long periods of time (Lubell 2013).

Pralle (2003), on the other hand, places primary emphasis on structural barriers and the cultural and ideological pre-dispositions of group leaders. Taken together, she argues that groups 
develop preferences for certain venues, meaning that potential opportunities in other venues are often missed because groups will not strategically change course (Pralle 2003, p. 242).

Finally, Baumgartner and Jones (1993) emphasize the critical interplay between image framing and a venue's image receptivity — the idea of an amiable venue. Successful political actors can either manipulate images to favor their preferred venue, or react to a changing image by altering their choice of venue. The problem with this second choice, however, is that the actor's ability to influence policy outcomes may diminish since there is no guarantee that the new venue will be favorable to their interests.

These theories are all useful in their own way, but also limited in their efficacy given the complex empirical realities of venue shopping that are demonstrated in our cases. Instead, the evidence from our case studies supports a synthetic adaptive learning framework in which several of the elements in existing venue choice theories are evident, yet not individually capable of explaining the choices made in our cases. Our AVS Framework describes how emergent groups with a mission, in this case, to clear the air of the pollutants associated with field burning, are choosing venues using a strategic calculation, or assessment, based on the institutional context where multiple policy games are playing out. Of central importance is the discovery that during the years-long environmental battles we analyze, emergent groups willingly adapted when their initial strategic choices fell short and applied what they learned to new venue choices where the goal of policy change later became fulfilled.

When emergent environmental groups are choosing venues, three important elements shape the institutional context: the group's mix of political, legal and technical resources; opponents' resource strengths; and the degree of venue accessibility, which is a combination of 
opponents' degree of control over a venue and a venue's image amiability or receptivity (see Table 1).

\section{The Institutional Context}

\section{Group resources}

Groups and alliances participating in the policymaking process have access to three main types of resources that they utilize in their quest for their preferred policy outcomes. The three forms of resources are political, legal, and technical. Groups can develop political resources in a number of ways. Some examples include using lobbyists, undertaking large-scale mobilization campaigns to cultivate public opinion, or working closely with leading legislators or powerful policy entrepreneurs already favorably disposed to a group's preferred policy outcome. When groups possess legal resources they have the ability to access and deploy legal expertise capable of recognizing the opportunities and constraints posed by laws, regulations, and the court system. Technical resources are developed through the quality and amount of factual and scientific evidence in support of a group's position. These resources, or the ability to 'access' them even if created by others, or by events and crises, is necessary if a group has any hope of successfully achieving its goals.

Yet, simple possession and deployment of a particular form of resource does not always equate with the fulfillment of a group's policy goals since different venues are more or less receptive to the type of resource possessed by a group (Sabatier and Jenkins-Smith 1999, p. 143). For example, groups with strong legal resources have a natural affinity for the courts, while those with strong political resources are likely to prefer legislative venues. Technical resource strength often confers an advantage in administrative decision venues, yet is also a resource that is helpful 
for both political and court-based venues, especially in highly technical policy areas such as human health and environmental harm.

\section{TABLE 1 ABOUT HERE}

\section{Opponents' resources}

The emergent groups in our case studies, however, did not make choices over where to shop based solely on their own resource strengths or weaknesses. Consideration is also given to the mix and strength of opponents' resources. This is because they know that the true strength of their own group resources are not absolute, but rather are relative to opponents' strengths as applied to possible venues.

\section{Venue accessibility}

The degree of venue accessibility also matters to groups. Accessibility is a function of an opponents' degree of control over a venue and a venue's image amiability or receptivity (Baumgartner and Jones 1993). Groups make this calculation because the transaction costs associated with venue choice vary with the degree of venue dominance by opponents and how favorable a venue is to a group's preferred image framing. Strong dominance by opponents and low image amiability in a particular venue increase the transaction costs for those seeking policy change because it increases the costs a group must devote to fulfill its goal of policy change, while a weak presence by opponents and high image amiability necessarily lowers expected transaction costs (Sabatier and Jenkins-Smith 1999).

The degree of opponent control or dominance of a venue is separate from a group's resource levels precisely because not all groups successfully translate a high level of resources into a similar degree of venue dominance. In some cases the lack of success is simply due to 
group ineffectiveness. However, the nature of certain venues works against a strong correlation between resource level and venue dominance because venue decision rules (e.g., courts and stare decisis; administrative agencies and the role of administrative law) and structure (administrative agencies and career bureaucrats) can and do mitigate the effects of high resource levels, no matter how effectively they are applied.

A venue's image receptivity, on the other hand, considers how different 'frames' of an issue are perceived and received by the different legislative, judicial, administrative, and collaborative venues. Groups often seek to define and frame public problems in ways that gain the attention of, and therefore influence, the policymakers that matter in the various institutional venues (Baumgartner and Jones 1993, Stone 2001). As part of this, there is an ongoing and critical interplay between image framing and a venue's image receptivity. Successful political actors are sensitive to this interplay and try to manipulate images to favor their preferred venue.

From an emergent group's perspective, a venue's image receptivity can and does have a connection to the degree of dominance exercised by opponents over specific venues. For example, if an opponent's resources translate into strong dominance of a venue then it is considered blocked, hence a poor venue to advance the emergent group's interests and one in which image receptivity is not a factor. Yet, if an opponent's degree of control is weak or leaves a venue contested (neutral), then image receptivity comes into play as a factor in venue choice.

In short, the Adaptive Venue Shopping (AVS) Framework posits that emergent groups, to the best of their ability, strategically assess the institutional context and choose a policy venue most favorable to the policy change they seek. Table 2 displays the AVS Framework in action as applied to a group's two easiest venue choices - the 'best' and 'worst' choices for achieving, or not, a preferred policy outcome. The easy 'best' choice for an emergent group seeking to change 
policy is when the group possesses a high level of resources 'matched' to a venue, opponents possess weak resource levels with respect to the same venue, opponents have weak control over the venue, and the venue has a strong reputation for favoring the emergent group's image of the policy in question. Venues to be avoided — the easy 'worst' choice—display a mix of weak emergent group resources with respect to the venue, strong opponent resources, strong dominance of the venue by opponents, and low image receptivity (amiability).

Venue choices for new groups, of course, are not always easy because, as described in the introduction, the deck is often stacked against them by entrenched, powerful opponents. This means that emergent groups can, and do, make flawed venue choices despite their intention to make the 'best' one. To anyone familiar with bounded rationality this is not surprising, but the key to the Adaptive Venue Shopping Framework is what happens after such failed choices. The field burning cases outlined below show that emergent groups learn and adapt by moving on to another policy venue where they expect, and in these two cases, secure better results.

\section{TABLE 2 ABOUT HERE}

\section{Research methodology}

This study uses a multiple case study design to probe the question of venue choice. Multiple case studies are appropriate when research questions require in-depth and contextual analysis, and ask 'why' actors behave the way they do (Yin 2009). This study builds a synthetic framework that identifies the variables that matter to groups as they are making venue choices. ${ }^{1}$ We chose to limit our analysis to the policy conflict over agricultural field burning in the Pacific Northwest because it involved a similar environmental conflict that lasted over an appropriate

\footnotetext{
${ }^{1}$ For more on the development of synthetic frameworks, see Cairney (2013)
} 
period of time in each of the states (more than ten years). Furthermore, our cases control for ideology, culture, and geography because both policy conflicts occurred in the Inland Northwest regions of Eastern Washington and Northern Idaho. This feature of our research design meets Gerring's (2001) description of similar cases and a most-similar research design where, 'a few cases... are as similar as possible in all respects except the outcome of interest, where [the cases] are expected to vary' (p. 210). Our data include personal interviews conducted with farmers, representatives from the grass seed industry, personnel from administrative agencies, lawmakers, journalists, advocacy groups, and attorneys. In all, we interviewed 35 individuals across the two states through a snowball sampling method and also include archival data from local newspaper accounts, public meeting records, and organizational newsletters. We turn now to our cases.

\section{Agricultural field burning in the Inland Northwest}

Lawns and golf courses around the world are planted and maintained with Kentucky Bluegrass seed grown in eastern Washington State and northern Idaho. Since the 1940s, farmers in both states have burned the plant's post-harvest crop residue because they believe doing so 'shocks' plants into production, exposes the plant to more sunlight, and minimizes the growth of weeds. The practice also minimizes labor costs and soil erosion because, without field burning, farmers replant their fields every three to four years, compared to the six to eight years required for burned fields.

Field burning also poses public health risks because minimizing the impact of smoke by burning when favorable weather conditions permit is complicated by unpredictable wind patterns that push smoke into the densely populated areas of Spokane, Washington and Coeur d'Alene, Idaho. Efforts to regulate the practice by single jurisdictions tend not to work because smoke 
drifts across state and county lines, causing doctors to warn those with asthma, cystic fibrosis, and other respiratory illnesses to stay indoors or leave during the field burning season that extends from August through October. Finally, tourists and recreational enthusiasts avoid visiting the region during the summer burning period, even though they are attracted to the beautiful forests, rolling hills, streams and lakes, and abundant wildlife.

By the early 1990s, there was mounting pressure in both states for policy change as public acceptance of relatively unrestricted field burning diminished. Environmentalists and public health advocates in Idaho and Washington used this opportunity to pursue policy change, and succeeded by instituting stronger burning restrictions that resulted in clearer skies. Yet the same policy goals in these two states were pursued in different institutional venues, with Idaho environmentalists twice choosing the judicial venue, while advocates in Washington opted for collaboration before successfully pursuing a mixed venue strategy employing a local administrative-legislative venue coupled with a state-level administrative venue.

\section{Idaho field burning and venue choice: a judicial strategy}

The public health risks associated with field burning in Idaho led to the formation of Safe Air for Everyone (SAFE) in the late 1990s. SAFE began as a coalition of interests from the medical community (i.e., Idaho Medical Association) and clean air advocates (i.e., the American Lung Association), but later added support from the real estate industry and local Chambers of Commerce due to concerns that field burning was impacting the local real estate and tourism economy (Olsen and Hollander 1999). Despite SAFE's modest beginnings, its membership grew to 400 members by 2002 (Russell 2002). How did this emergent group approach its venue shopping choices? The short answer is that they selected two venues across a span of roughly 
five years (2002 to 2006), targeting each venue on the basis of their own resource strengths, their opponents' strengths, their opponent's degree of control over different venues, and the expected image receptivity of a venue.

\section{Choosing the federal courts}

Despite being a broad-based coalition, SAFE, 400-strong, was still quite small and unlikely to wield much political clout relative to the rest of Idaho where concentration of population in and around the southern city of Boise, the state capital, is concentrated. Grass growers, consisting of about fifty individual farming operations, were also well organized through their professional association, the North Idaho Farmer's Association (NIFA). NIFA assessed 'per-acre burning fees' which allowed the group to raise funds for continuously lobbying the legislative and executive branches of Idaho government to protect farming practices from regulation. NIFA also maintained close relationships with other extractive industries tied to agriculture, such as mining and forestry interests. This alliance conferred a significant political advantage, especially in the legislature, given that agriculture, mining, and forestry together dominate Idaho's economy by contributing \$3.6 billion, or fourteen percent of GDP (Idaho Department of Labor 2009).

The political dominance of agricultural and other extractive industries explains why grass growers were comfortable with a legislative strategy. In 1980, at the behest of the Idaho Farm Bureau, Idaho passed one of the nation's first and strongest right-to-farm laws that protected agricultural practices from lawsuits (the law's protections were enhanced more in 2003). The dominance of the legislature by farmers and their allies also helps to explain the lax enforcement of Idaho's State Implementation Plan (SIP) for the federal Clean Air Act (CAA). Idaho's SIP was approved by the U.S. Environmental Protection Agency (EPA) in 1972. It limited field 
burning in all areas of agriculture because of recognized human health risks and handed enforcement authority to the Idaho Air Quality Board. Yet, the legislature abolished the agency, before reestablishing it in 1982, and renaming it as the Department of Environmental Quality, with a caveat listing field burning as an allowable source of pollution under the CAA. The legislature then repealed rules on agricultural burning in 1986 (Dukes 2007b, Idaho Department of Environmental Quality 2008). Finally, in 1999 Idaho lawmakers passed legislation placing regulatory jurisdiction over field burning in the Idaho State Department of Agriculture (ISDA), a clientele agency designed to promote, not regulate, the agricultural industry.

In sum, the ability of SAFE's opponents to dominate and effectively block access to the state-based legislative and administrative venues, and the historical acceptance of an economic growth 'frame' across both legislative and administrative institutions in Idaho (Powers and Barrett 2001), signaled that a judicial venue offered SAFE the best bet for successfully pressing its agenda (see top portion of Table 3). The executive director of SAFE expressed the organization's frustration about the likelihood of positive legislative action:

The Legislature has never really taken the lead on ensuring the public health, so we'll continue to work any and all avenues that we can in order to make sure that the Legislature understands the public health crisis. We would prefer not to go to court, but in the absence of any clear leadership, we most certainly will be prepared to take that step if we have to (Hedberg 2002).

Another interviewee put it more succinctly, 'there was no legislative solution. The legislature was part of the problem' (Personal Interview, PHA).

Compared to SAFE's limited political resources, the group's access to legal resources from outside groups and from public interest attorneys who volunteered their talents made legal resources their strongest resource. This blend of factors led SAFE to choose the courts, but a history of state judicial decisions that consistently favored economic interests and the state's clear right-to-farm laws prevented such suits from being filed in state courts. The federal courts, 
on the other hand, have established a decades-long track record of being receptive to a public health framing when suits are filed under environmental laws like the CAA (Weber 1998). This receptivity to SAFE's preferred legal 'framing' of the battle over field burning was reinforced by the fact that Idaho is under the jurisdiction of the Ninth Circuit Court of Appeals, a federal appellate court with a reputation for handing down liberal rulings in the area of environmental and human health hazards.

\section{TABLE 3 ABOUT HERE}

In February 2002, SAFE filed suit against Idaho growers under the Resource Conservation and Recovery Act (RCRA) (42 U.S.C. § 6901), which regulates the disposal of hazardous waste. SAFE argued that crop residue constitutes a solid waste material that, when burned, becomes hazardous and requires regulatory action by the EPA. The decision to file suit under RCRA was a critical one for SAFE because, in doing so, they became committed to pursuing their goals through the federal court system and generated new technical resources to go along with their legal resources. To this end, their strategy included recruiting

[e]xpert witnesses [who] were retained to demonstrate that grass residue met the legal definition of agricultural waste as defined by RCRA; that the smoke which was making people ill was in fact originating from grower's [sic] fields, and that the high particulate readings on air quality monitors were correlated with symptoms seen in the general public complaint records (SAFE 2002).

After three days of oral arguments before the Federal District Court in Boise, ID, SAFE's suit was dismissed after the judge ruled that burned crop residue did not meet the definition of hazardous waste. According to the judge, 'The Court finds the burning of residue is not a "disposal" and, further, the residue is not a "solid waste" because it is neither discarded or [sic] abandoned, but instead, used as part of the growth process. Therefore RCRA does not apply' (Alkire 2002). 


\section{Doubling down on the federal courts}

Despite the judge's decision in the case, SAFE was emboldened to continue seeking a legal victory through the federal court system and did so again in 2006 (see lower portion of Table 3), but the organization remained active at the state level as well. In the meantime, it maintained its core group of members by playing defense as best it could in the state-based legislative and administrative venues, while also supporting efforts to improve the quantity and quality of the scientific information they were collecting. In fact, despite losing the RCRA court case, SAFE continued using the scientific resources generated from its activities in the judicial venue. The case "created a public record - a very undisputed record - about how this practice harms people. [We] still couldn't find a legal angle to stop this practice but it was sort of this moving train about here's how harmful the [field burning] is' (Personal Interview, ATY).

In addition, the case strengthened SAFE's legal resources by creating new professional relationships with other attorneys involved in federal public health and environmental litigation. During SAFE's appeal of the RCRA decision to the Ninth Circuit, the group developed relationships with Sierra Club's legal organization, Earthjustice. Their interactions with these attorneys led to the discovery of a fatal flaw in Idaho's SIP that led to the maintenance of a court-based strategy, policy change, and thus, the fulfillment of SAFE's policy goals.

While examining Idaho's SIP, the group found Idaho did not articulate field burning as an allowable source of air pollution (Smith 2005). SAFE then notified state officials within the ISDA of the omission and that it was prepared to litigate the issue in federal court. Opponents of SAFE — the pro-field burning interests — acted to preempt the lawsuit by passing legislation amending the SIP during the 2005 legislative session. The amendment specifically recognized field burning as an allowable form of pollution under the CAA, a revision that EPA approved 
that year. Members of SAFE protested the move by 'the farm-lobby-legislature' and the fact that 'EPA rubber stamped it' (Personal Interview, PHA) because, from their perspective, EPA failed to assess the public health impacts of field burning prior to accepting the change in the SIP. EPA's response was that, in approving the amended SIP, it was clarifying what had already been existing practice in Idaho (Geranios 2005). SAFE appealed this decision, arguing that the EPA violated the Administrative Procedures Act by not considering the public health consequences of approving the practice of field burning (Smith 2005).

After SAFE appealed the EPA's decision, the case immediately came before the Ninth Circuit Court of Appeals. Interpreting the plain meaning of Idaho's SIP, the three judge panel agreed that EPA's approval of the SIP was 'arbitrary and capricious.' The court thus ordered the EPA to reconsider its approval of field burning and required Idaho to conduct a comprehensive analysis of field burning's impact throughout the state (Dukes 2007a). In response to the decision, and with farmers and lawmakers growing weary of continued litigation over field burning, Idaho Governor Butch Otter (R-ID) supported the idea of the ISDA spearheading a compromise between SAFE and the growing community to resolve the persistent problem of field burning. By January 2008, a tentative agreement between farmers and public health interest culminated in a new smoke management program transferring regulatory jurisdiction over field burning to the Idaho Department of Environmental Quality, an agency designed to improve air quality and with power to declare air quality emergencies (Buley and Stewart 2008, Hedberg 2008). The negotiated agreement, which required final approval from the Idaho State Legislature, then passed the legislature unanimously and was signed by Governor Otter in March 2008.

\section{Washington Field Burning and Venue Choice: A Multi-Venue Strategy}


In 1998, the State of Washington, through its Department of Ecology (DOE), became the first state to ban the burning of bluegrass. Most field burning occurred in eastern Washington near the city of Spokane, which was within five miles of the northern Idaho region described in the previous case study. This case explains how Washington arrived at their field burning ban and describes the multiple venue choices made by clean air advocates along the way to their final success. In short, after analyzing the institutional context--their own in-group resources, opponents' resource strengths and their dominance of particular venues, and venues' receptivity to their 'framing' of the problem — clean air advocates in Washington moved in a decidedly different direction than SAFE did in Idaho. Instead of the courts, they initially chose a collaborative decision-making arrangement (see top of Table 4). But finding no success there, and with the advent of a better organized advocacy group called Save Our Summers (SOS), clean air advocates shifted strategy and successfully sought policy change through both a local, mixed administrative-legislative (elected board) venue and a state-level administrative venue (see bottom of Table 4).

\section{TABLE 4 ABOUT HERE}

\section{A tough setting leads to a collaborative venue}

Jurisdiction over air pollution in Washington State rests with the Department of Ecology. In order to tailor regulatory policy to local jurisdictions, the state's1967 Clean Air Act grants concurrent regulatory authority to county-based boards such as the Spokane County Air Pollution Control Authority (SCAPCA). ${ }^{2}$ SCAPCA's five appointed members are selected by the County Commission, two cities (Spokane, City of Spokane Valley), several smaller cities in the County, and one at-large member from the community. The inherently conservative nature

\footnotetext{
${ }^{2}$ SCAPCA was later renamed Spokane Clean Air.
} 
of Spokane County politics allowed farmers to focus their efforts on influencing the selection of board members sympathetic toward agricultural practices. To advance these efforts, growers formed the Intermountain Grass Growers Association (IGGA) in the 1960s to monitor SCAPCA activities and to regulate field burning only minimally. While some citizens attended meetings to complain about air quality in those early days, they were unorganized and not able to compete with the influence of IGGA.

By 1987, Spokane violated federal CAA standards governing small particulate matter, so DOE and SCAPCA began assessing the inventory of practices contributing to poor air quality. Without widespread public support and in the absence of any advocacy groups to support its effort, SCAPCA proposed new regulations in 1990 that reduced the 'burning season' and the numbers of acres to be burned from roughly 31,000 in 1990 to 18,108 in 2000 . Over 200 members of the grass growing community arrived at the public hearings to oppose the new rules (Bayne 1990), outnumbering the handful of citizens testifying in favor of stricter controls (Sullivan 1990). In the end, IGGA and pro-field burning interests succeeded in watering down the new rules by increasing the 1990 baseline to 35,000 acres and allowing field burning to continue into the indefinite future without any reduction in acreage (versus a phase-out) (Yates 1990, Spokane County Air Pollution Control Authority 1990).

Opposition toward the practice of field burning escalated when it became evident that little was being done to regulate the practice, causing a group of loosely organized stakeholders, led by the American Lung Association, to begin addressing the problem through a collaborative institution. Advocates for cleaner air recognized that the 'clean air' frame they were trying to advance could not compete in regulatory agencies with the grass growers' claim, supported by strong technical resources and classical economic theory, that regulatory limits on field burning 
guaranteed the economic demise of the grass seed industry. The general lack of resources, whether legal, technical or political, within the nascent clean air coalition led its members to embrace the collaborative possibility as perhaps their best, if not only, chance to achieve their agenda of less field burning and cleaner air.

Coupled with their resource calculation, clean air advocates knew that, by definition, a collaborative institutional forum gave them a fighting chance because its primary purpose was to produce win-win outcomes in which all stakeholders are made better off than before. Additionally, stakeholders besides clean air advocates began noticing the negative effects of field burning in the region. One was the Soil and Water Conservation Society (SWCS), which produced a position statement explaining how '[c]onflicting interests have become so polarized and emotion-charged that it may be very difficult to achieve a rational solution,' while also calling for the 'effective resolution of conflicts and resource use problems arising from this issue' (Soil and Water Conservation Society 1990, p. 2). Shortly afterward, the Spokane Chamber of Commerce declared 'the need to preserve and improve air quality in the Inland Northwest' (Spokane Chamber of Commerce No Date). The chamber recognized that 'the grass seed industry is an important economic force in the regions [sic] economy' (Spokane Chamber of Commerce [No Date]), but nevertheless joined with clean air advocates to participate in the Inland Northwest Field Burning Summit between 1990-1995. Other Washington State interests included farmers and seed processing companies who used the summit to show how the industry already had in place voluntary regulations through IGGA. On the public health side, the loose coalition of tourism interests, the American Lung Association, the medical community, SCAPCA, and the Washington State Department of Ecology participated in hopes of breaking the policy gridlock over field burning. 
Although the primary purpose of the collaborative summit was for stakeholders to find alternative ways to reduce or eliminate the impact of smoke from field burning altogether, almost no progress was made toward resolving the field burning problem during its five year existence. In 1994, the American Lung Association announced its withdrawal from the summit, expressing frustration that the collaborative process was making little progress toward reducing the impact of smoke (American Lung Association 1994). When SCAPCA hired a new Executive Director who was committed to stricter controls over field burning, growers also announced plans to withdraw from the summit. The dissolution of the Inland Northwest Field Burning Summit summit became official when, in 1995, farmers secretly and successfully convinced Washington state legislators to pass a law weakening SCAPCA's ability to pass regulations affecting growers.

The unanimous passage of Senate Bill 5609 in both the Washington House and Senate was a moment that forever changed field burning politics in Washington State. The bill preserved SCAPCA's authority to regulate the number of acres burned, but the agency was no longer able to set burning seasons nor could it ban burning on weekends and holidays. In short, farmers were still required to respect limits on how many acres they burned, but they could burn whenever they wanted, and this meant more days with smoke in the air (Camden 1995).

Strategic adaptation: a simultaneous two venue strategy

The decision by growers to weaken SCAPCA's authority caused an organized public backlash against field burning, which led to clean air advocates formally establishing the citizens' group known as Save Our Summers in May 1995. Their mission was to eliminate field burning and thereby create 'a beautiful and healthy place for all of us to breathe and raise our children' (Save 
Our Summers 1996). SOS grew quickly and chose a two-pronged strategy for pressing its fight against field burning.

SOS started where it was strongest. With a group of politically mobilized citizens at the local level, SOS gravitated toward the increasingly contested and accessible SCAPCA, which was regulatory in character. Whatever dominance growers still exercised over the board was further diminished as complaints to the air pollution control hotline increased (278 complaints were registered in 1995), and large numbers of citizens against field burning, often 80 to 90 percent of the audience, started dominating SCAPCA meetings (Steele 1995). Finally, in 1995, SCAPCA added a new board member who was publicly opposed to field burning and sympathetic to the public health claims emphasized by SOS (Steele 1995).

SOS also began generating technical resources. They did so by gathering medical data and developing relationships with Spokane's medical community, including the American Lung Association. These new allies brought the power of expertise to bear on behalf of SOS because many doctors 'believed that the medical information - the scientific information - showed that the smoke was a hazard... [A] survey [of] the entire society of physicians [in Spokane asked] ... whether grass burning smoke was a health problem. Out of the 600 members, 580 responded, yes, it was' (McLeod 2005). With the medical community’s help, in late 1995 SOS succeeded in convincing the local-administrative board to vote 3-2 to institute a field burning phase-out in Spokane County over a seven-year period. Since this new local rule focused on field burning acreage only, it fit within the state-based law passed earlier in 1995 by the Washington legislature (the law weakened SCAPCA's ability to tell farmers when they could burn, but did not rule out elimination of the practice). 
Yet, while SOS was pursuing change through SCAPCA it was concurrently seeking to convince the state-level DOE to ban field burning because the problem was not confined to Spokane County, and the agency had the power to end the practice statewide. Given DOE's overarching regulatory jurisdiction over field burning in the state of Washington, and the fact that SCAPCA had been dominated through the years by growers, the strategy made sense. SOS's technical resources, generated from its relationships with the medical community and American Lung Association, matched well with the agency's professionally trained staff, who were fluent in the science behind environmental and public health problems and sympathetic to a 'public health' framing of the problem. The Clinton Administration's emphasis on rewriting rules for small particulate matter generated even more convincing evidence that SOS was able to mobilize before the environmental agency, particularly the series of Harvard-based epidemiological studies linking mortality with exposure to small particulate matter (Schwartz, et al. 1996, Personal Interview, SR). SOS also knew that, in addition to having the right resources to bring before an agency, it also needed an agency that was receptive to its preferred framing of the problem. SOS considered that, of all the agencies responsible for regulating environmental issues, DOE was the agency most sympathetic to its 'public health' framing of the problem and the one most likely to act in favor of public health benefits when weighed against the economic costs of pursuing them (Personal Interview, PHA).

After SOS successfully convinced SCAPCA to support an end to field burning in 1995, growers responded by asking the DOE to overturn the decision by writing statewide rules governing the practice of field burning (Steele 1996a). Their efforts were rebuked by DOE personnel, many of whom were involved with the Inland Field Burning Summit and had concluded that farmers acted in bad faith by no longer working through the collaborative process 
when they went before the legislature to alter SCAPCA's regulatory powers. Furthermore, the scientific evidence linking fine particulate matter to mortality was becoming impossible for DOE personnel to ignore (Personal Interview, SR); DOE expressed support for SCAPCA's decision to phase out field burning and issued a directive that formally supported the decision (Steele 1996b). One DOE official noted that 'the research on the health effects of particulate matter was instrumental, so as we got better science about what the consequences were, that just added momentum and courage to ... agency [decision-makers when it came] ... to mak[ing] this difficult choice. It didn't hurt that some of that research was conducted very close to home at the University of Washington and Washington State University' (Personal Interview, SR).

The battle in Washington over field burning ended after DOE funded a study that was completed by Washington State University economists concluding that the public health costs of the practice outweighed its economic benefits (Washington Department of Ecology 1997). With persuasive evidence supporting its decision to act affirmatively, the DOE ended the burning of Kentucky Bluegrass completely in 1998.

\section{Discussion and conclusion}

The policy battles that occurred over the problem of field burning in Washington and Idaho illustrate how emergent groups view, react, learn, and adapt to the larger institutional context when shopping for a policymaking venue most conducive to their overall policy goals. While we are confident in our results, the findings at this point are suggestive and necessarily stand as testable hypotheses since they are derived from multiple case studies. To establish a more definitive interpretation of such results, we encourage scholars to consider additional testing through a larger series of venue shopping cases involving more than a single policy area or 
controversy. While our insights support many individual aspects of existing approaches to venue shopping, the key theoretical lesson is that a synthetic approach, which we call the Adaptive Venue Shopping (AVS) Framework, is better able to capture the complexity of choice facing emergent groups in a multi-venue ecology of games that can and does change over time given the capacity of groups to learn and adapt their venue choice strategies.

The practical takeaway, for its part, should be encouraging to newly formed advocacy groups seeking change in environmental policy and other policies too. This is because, despite the resource limitations that are almost always part of the equation for new groups, the AVS Framework communicates a method for analyzing the larger institutional context, identifying venues vulnerable to policy change, and then crafting an effective venue choice approach based on that analysis. At the same time, the AVS Framework recognizes that just because initial venue choices, no matter how rational they appeared at the time, do not result in the desired policy change, the learning, adaptation, cumulative resources, and new allies that come from these early venue battles can point the way toward other venue choices likely to be even more amenable to policy change.

\section{References}

Alkire, T., 2002. Bureau of National Affairs Daily Environment Report, July 24.

American Lung Association, 1994. End to burning overriding concern. The Spokesman Review, 7 October, Sec. B.

Baumgartner, F. and Jones, B., 1991. Agenda dynamics and policy subsystems. Journal of Politics, 53 (4), 1044-1074.

Baumgartner, F. and Jones, B., 1993. Agendas and instability in American politics. Chicago: University of Chicago Press.

Bayne, N., 1990. Officials dampen hopes of growers: grass seed cuts posed. Agri-Times, 23 March, p. 6.

Brick, P.,, and Cawley. R.M., 2008. Producing political climate change: the hidden life of U.S. environmentalism. Environmental Politics 17 (2): 200- 218.

Buley, B. and Stewart, M., 2008. Deal brings back field burning. The Coeur d'Alene Press, January 12 , Sec. A. 
Cairney, P., 2013. Standing on the shoulders of giants: how do we combine the insights of multiple theories in public policy studies? Policy Studies Journal, 41 (1), 1-21.

Camden, J., 1995. Clash expected over burning regulations: change in law pits clean air activists against grass growers. The Spokesman Review, July 19, Sec. B.

Dukes, L., 2007a. Farmers look for answers to field-burning ban. The Coeur d'Alene Press, March 14.

Dukes, L., 2007b. Court throws water on field burning. The Coeur d'Alene Press, May 30, Sec. A.

Geranios, N., 2005. Clean-air activists sue EPA over field burning in Idaho. The Columbian, December 16, Sec. C.

Gerring, J., 2001. Social science methodology: a critical framework. Cambridge: Cambridge University Press.

Hedberg, K., 2002. SAFE will sue to stop burning. Lewiston Morning Tribune, February 7, Sec. A.

Heberg, K., 2008. Wheat should fly high a little longer. Lewiston Morning Tribune, January 5, Sec. C.

Heikkila, T. and Gerlak., A.K., 2013. Building a conceptual approach to collective learning: Lessons for public policy scholars. Policy Studies Journal, 41 (3), 484-512.

Idaho Department of Environmental Quality, 2008. Crop residue burning state implementation plan. Boise, ID: Idaho Department of Environmental Quality.

Idaho Department of Labor, 2009. Idaho gross domestic product. Boise, ID: Idaho Department of Labor.

Lubell, M., Henry, A.D. and McCoy, M., 2010. Collaborative institutions in an ecology of games. American Journal of Political Science, 54 (2), 287-300.

Lubell, M., 2013. Governing institutional complexity: the ecology of games framework. Policy Studies Journal, 41 (3), 537-559.

McLeod, M., 2005. Washington state Department of Ecology historically speaking: an oral history of the first 35 years, 1970-2005. Olympia, WA: Washington State Department of Printing.

Olsen, K., and Hollander, Z., 1999. Solution to torching grass fields still hazy: despite outcry and research, practice continues. The Spokesman Review, August 8, Sec. B.

Powers, T. and Barrett, R., 2001. Post-cowboy economics: pay and prosperity in the new American West. Washington, D.C.: Island Press.

Pralle, S. B., 2003. Venue shopping, political strategy, and policy change: the internationalization of Canadian forest advocacy. Journal of Public Policy, 23 (3), 233260.

Rootes, C. 2013. From local conflict to national issue: when and how environmental campaigns succeed in transcending the local. Environmental Politics, 22 (1), 95-114.

Russell, B., 2002. Clean air activists launch anti-burning drive - Idaho Medical Association and American Lung Association join Sandpoint group. Idaho Spokesman Review, January 5, Sec. A.

Sabatier, P. and Jenkins-Smith, H., 1999. The Advocacy Coalition Framework: an assessment. In: P. Sabatier, ed. Theories of the Policy Process. Boulder, CO: Westview Press, pp. 118-188.

SAFE, 2002. Conflicting missions: DEQ and ISDA-smoke management efforts 2002, a White Paper. Sandpoint, ID: SAFE. 
Save Our Summers, 1996. Newsletter. Spokane, WA: Spokane Clean Air.

Schwartz, J., Dockery, D.W. and Neas, L.M., 1996. Is daily mortality associated specifically with fine particles? Journal of the Air \& Waste Management Association, 46 (10), 927939.

Smith, C., 2005. Groups sue EPA over field burning. The Twin Falls Times-News, September 10.

Soil and Water Conservation Society, 1990. The issue of open field burning of grass seed production residue in Northeastern Washington and Northern Idaho. Spokane, WA: Soil and Water Conservation Society.

Spokane Chamber of Commerce, No Date. Joint chamber policy position statement. Spokane, WA: Spokane Chamber of Commerce.

Spokane County Air Pollution Control Authority, 1990. Board meeting minutes. Spokane, WA: Spokane County Air Pollution Control Authority.

Steele, K. D., 1995. Roskelley gets seat on SCAPCA: new commissioner will replace Phil Harris on clean air board. The Spokesman Review, Dec 2, Sec. B.

Steele, K. D., 1996a. Growers try to halt burn rules: area grass farmers visit with Department of Ecology chiefs. The Spokesman Review, Mar 1, Sec. B.

Steele, K. D , 1996b. State to ban grass burning by 1998. The Spokesman Review March 20, Sec. A.

Stone, D., 2001. Policy paradox: the art of political decision-making. New York: W.W. Norton.

Sullivan, J., 1990. Impassioned pleas light up grass-burning debate. The Spokesman Review, Mar 15, Sec. A.

Washington Department of Ecology, 1997. Estimates of the benefits and costs from reductions in grass seed field burning. Olympia, WA: Washington Department of Ecology.

Weber, E. P., 1998. Pluralism by the rules: conflict and cooperation in environmental regulation. Washington, D.C.: Georgetown University Press.

Weible, C. M., 2007. An Advocacy Coalition Framework approach to stakeholder analysis: understanding the context of California marine protected area policy. Journal of Public Administration Research and Theory, 17 (1), 95-117.

Weible, C. M. and Sabatier, P., 2007. A guide to the Advocacy Coalition Framework. In: F. Fischer, G. J. Miller, and M. S. Sidney, eds. Handbook of Public Policy Analysis. New York: CRC Press, pp. 123-136.

Yates, S., 1990. Grass growers breathe easier as board votes: burn rules aren't overly restrictive. Capital Press, April 20.

Yin, R. K., 2009. Case study research: design and methods, fourth edition. Thousand Oaks, CA: Sage Publications. 
Table 1: The Logic of Venue Choice

Degree of Venue Accessibility

\begin{tabular}{|c|c|c|c|c|}
\hline Decision Venue & $\begin{array}{l}\text { Strength of } \\
\text { Group } \\
\text { Resources }\end{array}$ & $\begin{array}{l}\text { Opponents' } \\
\text { Resources }\end{array}$ & $\begin{array}{c}\text { Opponents' } \\
\text { Degree of } \\
\text { Dominance }\end{array}$ & $\begin{array}{l}\text { Venue Image } \\
\text { Receptivity }\end{array}$ \\
\hline Courts & Low to High & Low to High & $\begin{array}{c}\text { Weak, } \\
\text { Neutral/Contested } \\
\text { or Strong }\end{array}$ & Low to High \\
\hline $\begin{array}{c}\text { Administrative } \\
\text { Agencies }\end{array}$ & Low to High & Low to High & $\begin{array}{c}\text { Weak, } \\
\text { Neutral/Contested } \\
\text { or Strong }\end{array}$ & Low to High \\
\hline Legislature & Low to High & Low to High & $\begin{array}{c}\text { Weak, } \\
\text { Neutral/Contested } \\
\text { or Strong }\end{array}$ & Low to High \\
\hline $\begin{array}{l}\text { Collaborative } \\
\text { Institution }\end{array}$ & Low to High & Low to High & $\begin{array}{c}\text { Weak, } \\
\text { Neutral/Contested } \\
\text { or Strong }\end{array}$ & Low to High \\
\hline
\end{tabular}




\begin{tabular}{ccccc} 
Decision Venue & $\begin{array}{c}\text { Strength of } \\
\text { Group } \\
\text { Resources }\end{array}$ & $\begin{array}{c}\text { Opponents' } \\
\text { Resources }\end{array}$ & $\begin{array}{c}\text { Opponents' Degree } \\
\text { of Dominance }\end{array}$ & $\begin{array}{c}\text { Venue Image } \\
\text { Receptivity }\end{array}$ \\
\hline $\begin{array}{c}\text { Easy "best" } \\
\text { Choice }\end{array}$ & High & Low & Weak & High \\
$\begin{array}{c}\text { Easy "worst" } \\
\text { Choice }\end{array}$ & Low & High & Strong & Low \\
\hline
\end{tabular}


Table 3: Venue Choices in Idaho

\begin{tabular}{|c|c|c|c|c|}
\hline Decision Venue & $\begin{array}{c}\text { Group } \\
\text { Resources }\end{array}$ & $\begin{array}{l}\text { Opponent } \\
\text { Resources }\end{array}$ & $\begin{array}{c}\text { Accessibility/Opponent Venue } \\
\text { Dominance }\end{array}$ & $\begin{array}{l}\text { Accessibility/Venue } \\
\text { Image Receptivity }\end{array}$ \\
\hline \multicolumn{5}{|c|}{ Choosing the Federal Courts using RCRA } \\
\hline Courts (federal) & $\begin{array}{c}\text { High } \\
\text { (strongest) }\end{array}$ & High & Neutral & $\begin{array}{l}\text { High } \\
\text { (relative to others) }\end{array}$ \\
\hline $\begin{array}{c}\text { State } \\
\text { Legislature }\end{array}$ & Low/Limited & High & Strong & Low \\
\hline $\begin{array}{l}\text { Administrative } \\
\text { Agency }\end{array}$ & Low/Limited & High & Strong & Low \\
\hline \multicolumn{5}{|c|}{ Choosing the Federal Courts using the Clean Air Act and Administrative Procedures Act } \\
\hline $\begin{array}{l}\text { Courts } \\
\text { (federal) }\end{array}$ & High & High & Neutral & $\begin{array}{l}\text { High } \\
\text { (relative to others) }\end{array}$ \\
\hline $\begin{array}{c}\text { State } \\
\text { Legislature }\end{array}$ & Low & High & Strong & Low \\
\hline $\begin{array}{l}\text { Administrative } \\
\text { Agency }\end{array}$ & $\begin{array}{l}\text { Medium-High } \\
\text { (getting } \\
\text { stronger) }\end{array}$ & High & Strong & Low \\
\hline
\end{tabular}


Table 4: The Washington Case: Clean Air Advocates, Collaboration, and a Two Venue Adaptation Strategy

\begin{tabular}{|c|c|c|c|c|}
\hline Decision Venue & $\begin{array}{c}\text { Group } \\
\text { Resources }\end{array}$ & $\begin{array}{l}\text { Opponent } \\
\text { Resources }\end{array}$ & $\begin{array}{c}\text { Accessibility/Opponent Venue } \\
\text { Dominance }\end{array}$ & $\begin{array}{l}\text { Accessibility/Venue } \\
\text { Image Receptivity }\end{array}$ \\
\hline \multicolumn{5}{|c|}{ Choosing Collaboration } \\
\hline Courts (federal) & Low & High & Neutral & High \\
\hline $\begin{array}{c}\text { State Admin } \\
\text { Agency (DOE) }\end{array}$ & Low & Medium & Neutral & Medium-High \\
\hline $\begin{array}{l}\text { Administrative } \\
\text { Legislative } \\
\text { (SCAPCA) }\end{array}$ & Low & High & Strong & Low-Medium \\
\hline $\begin{array}{c}\text { State } \\
\text { Legislature }\end{array}$ & Low & Medium & Strong & Medium \\
\hline $\begin{array}{l}\text { Collaborative } \\
\text { Institution } \\
\text { (INFB Summit) }\end{array}$ & Medium & Medium & Neutral/Contested & High \\
\hline \multicolumn{5}{|c|}{ Choosing both the Local Administrative-Legislative and State Administrative Agency } \\
\hline $\begin{array}{l}\text { Courts } \\
\text { (federal) }\end{array}$ & Low & High & Neutral & High \\
\hline $\begin{array}{c}\text { State } \\
\text { Administrative } \\
\text { Agency (DOE) }\end{array}$ & Medium-High & Medium & Neutral & Medium-High \\
\hline $\begin{array}{l}\text { Administrative- } \\
\text { Legislative } \\
\text { (SCAPCA) }\end{array}$ & $\begin{array}{l}\text { Medium-High } \\
\text { (and growing) }\end{array}$ & High & Neutral/Contested & $\begin{array}{c}\text { Medium } \\
\text { (moving to High) }\end{array}$ \\
\hline $\begin{array}{c}\text { State } \\
\text { Legislature }\end{array}$ & Low & High & Strong & Low \\
\hline
\end{tabular}

